\title{
Strategic Positioning Affect Corporate Financialization
}

\author{
Yueying Li \\ College of Economics and Management, China Agricultural University, Beijing, China
}

1295694767@qq.com

\begin{abstract}
This paper examines the impact of corporate strategy aggressiveness on the trend of financialization. Taking Chinese A-share listed companies of Shanghai and Shenzhen stock market from 2007 to 2018 as samples, the study finds that there is a positive correlation between corporate strategy aggressiveness and corporate financialization, that is, the more aggressive the company is, the higher its degree of financialization will be. Further research in this paper finds that there is a grouping moderating role of profitability and analyst concerns in the mechanism of the impact of corporate strategy on corporate financialization. Companies with weaker profitability and higher analyst attention level are more likely to have financialization tendency. The research of this paper expands the influencing factors of corporate financialization, and confirms that the degree of corporate strategy aggressiveness has a positive impact on corporate financialization, which has important practical significance for promoting the further development of strategic management practice of China's non-financial listed companies.
\end{abstract}

Keywords: Corporate Strategy; Corporate Financialization; Profitability; Analyst Concerns.

\section{Introduction}

In recent years, market demand is shrinking, while more and more enterprises are overcapacity. Under this background, the rate of return on investment of real enterprises is declining and the growth of real economic is slowing. A lot of capitals take off the real to virtual and pour into the financial sector. Corporate entities own a lot of capital allocation in the virtual high degree of financial assets, which is called the "financialization" (Demir et al., 2009). Real enterprises deviate from their main business and the virtual economy prospers excessively, which make the financialization of real enterprises become an important topic that needs to be focused on and discussed by the theoretical and practical circles at present (Du Yong et al., 2019). In the research on the influencing factors of enterprise financialization, the existing literature has analyzed the influence of various factors on the financialization process of real enterprises from the macro-level such as market competition and industry division, as well as the characteristics at the financial level (such as leverage ratio and financing constraints) and the characteristics at the management level (such as CEO's financial background). However, on the whole, only a few scholars pay attention to the research on the influence of corporate strategy on financialization. Corporate strategy reflects the decision-making and development direction and management focus of the listed company, which has a very important impact on maintaining the sustainable development of the company and enhancing the core competitiveness of the company. The more aggressive corporate strategy is, the more willing it is to venture into the industry with great uncertainty but fast growth and high return rate (Higgins et al., 2015), and the more likely it is to have the tendency of corporate financialization. The classification of strategic types by Miles and Snow (2003) has been able to cover the existing mainstream classification of strategic types, which provides an important theoretical support for the measurement and research of the degree of corporate strategy aggressiveness. Studies by some scholars have found that corporate strategy will have an impact on salary incentives (Iittner et al., 1997), budget management (Collins et al., 1997), earnings management (Sun Jian et al., 2016), commercial credit financing constraints (Fang Hongxing et al., 2019), capital market pressure (Meng Qingbin et al., 2019), cash holdings (Gao Zhilin et al., 2020), etc.

This paper takes Chinese A-share listed companies of Shanghai and Shenzhen stock market from 2007 to 2018 as samples to study the influence of strategic aggressiveness on financialization choice of enterprises. It mainly investigates the following three questions: First, does the degree of strategic 
aggressiveness have an impact on the financialization trend of non-financial listed companies? What are the effects? Second, will the relationship between strategic aggressiveness and corporate financialization trend be affected by different conditions such as profitability and analyst concerns? This paper speculates that strategic aggressiveness may lead to non-financial firms have more allocation of financial assets, and then there will be some effect on the degree of financialization. Moreover, compared to the enterprises with strong profitability, enterprises with weak profitability are more likely to increase the proportion of financial assets to make up for the deficiency of the main business. At the same time, companies with high level of analyst concerns are also more likely to face the problem of financialization. Based on the robustness tests of substitution variables, cluster processing and Heckman, the results of the promotion effect of corporate strategy aggressiveness on enterprises financialization tendency are still stable.

The contributions of this paper are mainly reflected in the following three aspects: First, this paper focuses on the impact of strategic aggressiveness on the degree of corporate financialization. Meanwhile, there are few direct studies on the relationship between the two in historical studies. This paper confirms that a high degree of strategic aggressiveness can promote corporate financialization, and provides more ideas and perspectives for the research on the influencing factors of corporate financialization. Second, this paper not only studies the impact of strategy on corporate financialization, but also explores other possible influencing factors in its mechanism. At the same time, it analyzes the moderating role of profitability and analyst concerns in corporate financialization caused by strategic aggressiveness. All these have expanded relevant researches in the field of financialization. Thirdly, the research of this paper has practical significance and operability. By adjusting the degree of corporate strategic aggressiveness, the process of corporate financialization can be controlled, so as to make better strategic adjustment and risk control and avoid excessive financialization tendency.

The rest of this paper is arranged as follows: the second part is the literature review and research hypothesis, the third part is the research design, the fourth part is the results analysis, the fifth part is the robustness test, and the sixth part is the research conclusion.

\section{Literature Review and Research Hypothesis}

\subsection{Corporate Strategy}

Corporate strategy refers to have a more reasonable allocation of resources based on their own objective conditions, capabilities and long-term goals to match changes in internal and external environment. Moreover, companies can improve their operation efficiency, form their own core competitiveness and finally achieve sustainable competitive advantage and create value constantly (Oehmichen et al., 2017).

There have been many different ways to classify strategy types in the existing literature. For example, corporate strategy can be divided into product differentiation and cost leadership (Porter, 1980); It can be divided into exploratory and exploitative types (March, 1991); It can also be divided into product leadership, efficient operation and close customer (Treacy et al., 1995). Miles and Snow (2003) categorize strategy types from low to high in aggressiveness into defensive, analytical, and aggressive. At present, Miles and Snow's (2003) classification method is considered to be able to cover the mainstream strategic classification and is widely recognized and applied. Defensive companies are more stable and conservative, with narrow business scope and limited business practice. While aggressive companies tend to grow rapidly, expand quickly and have strong sense of innovation, but they are unstable. Analytical companies fall in the position between them.

Existing researches more focus on the company performance (Cui, 2011), and they think the corporate strategy can increase the enterprise's external financing constraints (Dimaggio et al., 1983), affect the quality of enterprise's financial information (Dichev et al., 2013) and surplus management (sun jian et al., 2016), reduce the accounting conservatism (Liu Xing, 2016), and increase audit fees (jin-feng Yang et al., 2019). 


\subsection{Corporate Financialization}

With continuous development and improvement of financial market, the proportion of financial assets in assets of real enterprises has become higher and higher, which is called corporate financialization. This phenomenon of financialization in non-financial enterprises in China is gradually becoming an important trend in the development of real enterprises. Corporate financialization refers to the financialization in non-financial enterprises, which means that corporate profits come more from financial investment rather than production and trade (Krippner, 2005). Existing studies show that many scholars believe that financialization in non-financial enterprises is a negative behavior. For example, Ohangazi (2008), Wang Hongjian et al. (2016) believe that the high return rate of financial asset investment will drive enterprises to intensify such cross-industry arbitrage behavior, deviate from their main business and reduce the efficiency of industrial investment.

There are three main views on the motivation of corporate financialization in academia. First, the study on "cash holding" leads to the precautionary motive of holding more cash (Keynes, 1936; Denis et al., 2010; Ang et al., 2011), enterprises with uncertain future cash flow and financing difficulties hold more cash to prevent the adverse effects of cash flow shocks (Opler et al., 1999); Second, financial derivatives are used to hedge and diversify risks (Bessembinder, 1991). Financial derivatives hedging can save taxes, reduce financial costs, improve capital operation efficiency and reduce operational risks of enterprises; Third, Cai Mingrong et al. (2014) put forward the profitseeking factor caused by the continuous decline in the profit of physical investment and the rising financial profit.

In the existing literature studies, scholars believe that the main factors influencing corporate financialization include the influence of macroeconomic environment (Deng Chao et al., 2017), the pressure of shareholder values (Deng Chao et al., 2017), and the uncertainty of economic policies (Peng Yuchao et al., 2018a).

\subsection{Corporate Strategy and Financialization}

Through the above sorting can be found, existing literature based on the viewpoint of strategic differences and type to explore the economic consequences of strategy. Most of the studies explore strategy how to affect enterprise financial, because asset structure, debt ratio and the information such as owner's equity in enterprise financial statements, to some extent, reflect the strategic intention of business development (He Xiqiong etc., 2018). The research on the influencing factors of financialization focuses more on the macro level. Few scholars have studied the impact on the financialization of enterprises from the perspective of corporate strategy. The style of corporate strategy is reflected in the degree of strategic aggressiveness, which will promote enterprises to have different risk preferences and differentiated choices. The higher the degree of strategic aggressiveness of an enterprise, the more it is inclined to make more radical decisions concerning the overall, longterm and fundamental nature of the enterprise, as well as the higher tolerance of the organization to failure (Francis et al., 1995; Yuan Rongli et al., 2020). These companies are more likely to take greater risks to pursue excess returns in the financial market, so that financial asset allocation squeezes out industrial investment (Zhang Chengsi et al., 2016), and the financialization level of enterprises is further promoted.

To sum up, this paper proposes hypothesis 1 (H1): assuming other conditions remain the same, companies with the higher degree of strategic aggressiveness will have a higher degree of financialization.

\section{Research Design}

\subsection{Sample Selection and Data Sources}

This paper selects Chinese A-share listed companies of Shanghai and Shenzhen stock market from 2007 to 2018 as the initial samples. The reason why the research started in 2007 is that China's listed 
companies began to implement the new accounting standards converging with the international accounting standards in 2007. On this basis, the sample of enterprises is screened, and the listed companies in the financial industry, ST and *ST enterprises, as well as the data defect value are excluded. In addition, in order to avoid the influence of extreme values on the research conclusion, Winsorize was carried out for all continuous variables in this paper. All data in this paper are from CSMAR database and WIND database.

\subsection{Variable Definitions}

\subsubsection{Explained Variable}

Corporate Financialization (FIN). Referencing the research of Du Yong et al. (2019) and Wu Jun et al. (2018), this paper uses the proportion of financial assets in total assets to measure the degree of corporate financialization of enterprises. Financial assets in the definition of financial assets ratio include trading financial assets, derivative financial assets, net interest receivable, net dividend receivable, net short-term investment, available for sale financial assets, net holding to maturity investment, net investment in real estate, long-term debt investment, and long-term equity investment.

\subsubsection{Explaining Variable}

Corporate strategy (STRA). Referencing the research of Bentley et al. (2013), this paper considers the start-up, production, operation and management of enterprises in the process of business operation comprehensively, and then constructs a discrete variable which can be used to measure corporate strategy, using the financial indicators of listed companies. This paper uses research and development intensity (research and development expenditure/ sales revenue), marketing strength (selling cost and management cost/sales revenue) and growth (the growth rate of sales revenue) three indicators to measure corporate entrepreneurial activity; Operation efficiency (number of employees/sales revenue) and capital density (net fixed assets/total assets) were selected to measure production and operation situation; Management performance is measured by headcount volatility (five-year headcount standard deviation/mean).Due to the lack of disclosure of research and development expenditure information by listed companies in China, domestic scholars generally use net intangible assets (minus land use right) to replace research and development expenditure level according to the research of Liu Hang et al. (2016). Take the average value of the above indicators in the past five years, and divide the mean value into five groups according to "year-industry" from small to large. The capital density index is assigned 0 to 4 from small to large, and the other indexes are assigned 0 to 4 from large to small. We can get a discrete variable STRA by summing up the assignments of the six variables. The higher the value is, the more aggressive the corporate strategy is. Conversely, the corporate strategy is more conservative.

\subsubsection{Control Variables}

Referring to previous studies by Yu Minggui et al. (2013) and Wang Hongjian et al. (2017), this paper introduced other control variables related to the level of financialization. Including enterprise size (Size), solvency (Lev), profitability (ROA), growth (Growth), cash flow (Cash), ownership concentration (First), fund-raising (Fund), board size (Boardsize), dual value (Dual), proportion of independent directors (Indep), audit quality (Big4).

Refer to the following chart 1 for details.

\subsection{Research Model}

In order to test the research hypothesis of this paper, that is, the relationship between corporate strategy and corporate financialization, we establish a multiple regression model as follows:

$$
\text { FIN }=\beta_{0}+\beta_{1} \text { STRA }+\gamma \text { Control }+ \text { Industry }+ \text { Year }+\varepsilon
$$

Among them, FIN is the index of corporate financialization, which is the explained variable. STRA is the index of corporate strategy, which is the explaining variable. Control represents the other 
Control variables selected in this article. In addition, in order to make the conclusion more robust, we also control dummy variables of Industry and Year.

Table 1. Variable definitions

\begin{tabular}{|c|c|c|c|}
\hline $\begin{array}{l}\text { Variable } \\
\text { type }\end{array}$ & Variable name & Symbol & Variable definition \\
\hline $\begin{array}{l}\text { Explained } \\
\text { variable }\end{array}$ & $\begin{array}{l}\text { Corporate } \\
\text { financialization }\end{array}$ & FIN & $\begin{array}{l}\text { (trading financial assets }+ \text { derivative financial assets }+ \text { net } \\
\text { interest receivable }+ \text { net dividend receivable }+ \text { net short-term } \\
\text { investment }+ \text { available for sale financial assets }+ \text { net holding to } \\
\text { maturity investment }+ \text { net investment in real estate }+ \text { long-term } \\
\text { debt investment }+ \text { and long-term equity investment) } / \text { total } \\
\text { assets }\end{array}$ \\
\hline $\begin{array}{l}\text { Explaining } \\
\text { variable }\end{array}$ & Corporate strategy & STRA & $\begin{array}{l}\text { Corporate strategy aggressiveness score. The higher the value } \\
\text { is, the more aggressive the strategy is. }\end{array}$ \\
\hline \multirow{11}{*}{$\begin{array}{c}\text { Control } \\
\text { variables }\end{array}$} & enterprise size & Size & Ln (total assets) \\
\hline & solvency & Lev & total liabilities/total assets \\
\hline & profitability & ROA & net profit/total assets \\
\hline & growth & Growth & $\begin{array}{l}\text { (current operating income- previous operating } \\
\text { income)/previous operating income }\end{array}$ \\
\hline & cash flow & Cash & net cash flow from operations/revenue \\
\hline & $\begin{array}{l}\text { ownership } \\
\text { concentration }\end{array}$ & First & equity concentration index \\
\hline & fund-raising & Fund & $\begin{array}{l}\text { (total liabilities and owners' equity- total current liabilities) } \\
\qquad / 100000000\end{array}$ \\
\hline & board size & Boardsize & Ln (number of directors) \\
\hline & dual value & Dual & 1 if the chairman and CEO hold concurrent positions; 0 if not \\
\hline & $\begin{array}{l}\text { proportion of } \\
\text { independent } \\
\text { directors }\end{array}$ & Indep & number of independent directors/total number of directors \\
\hline & audit quality & Big4 & $\begin{array}{c}1 \text { if the auditor is one of the top four international auditors in } \\
\text { the current year; } 0 \text { if not }\end{array}$ \\
\hline
\end{tabular}

\section{Results Analysis}

\subsection{Descriptive Statistics and Correlation Analysis}

Table 2. Descriptive statistics

\begin{tabular}{|c|c|c|c|c|c|c|}
\hline Variable & Number & Mean & SD & Min & Median & Max \\
\hline FIN & 15582 & 0.0771 & 0.1077 & 0.0000 & 0.0355 & 0.5841 \\
\hline STRA & 15582 & 11.8668 & 4.0650 & 3.0000 & 12.0000 & 21.0000 \\
\hline Size & 15582 & 22.2413 & 1.2728 & 19.3170 & 22.1218 & 26.0398 \\
\hline Lev & 15582 & 0.4728 & 0.2058 & 0.0686 & 0.4742 & 0.9890 \\
\hline ROA & 15582 & 0.0316 & 0.0623 & -0.2612 & 0.0300 & 0.2094 \\
\hline Growth & 15582 & 0.1833 & 0.5005 & -0.5587 & 0.0995 & 3.4797 \\
\hline Cash & 15582 & 0.0885 & 0.1679 & -0.5355 & 0.0728 & 0.6773 \\
\hline First & 15582 & 33.8437 & 14.8055 & 8.3523 & 31.5286 & 73.9694 \\
\hline Fund & 15582 & 70.3454 & 162.7081 & 0.3749 & 24.7256 & 1233.9504 \\
\hline Boardsize & 15582 & 2.1592 & 0.2010 & 1.6094 & 2.1972 & 2.7081 \\
\hline Dual & 15582 & 0.2030 & 0.4022 & 0.0000 & 0.0000 & 1.0000 \\
\hline Indep & 15582 & 0.3715 & 0.0534 & 0.3077 & 0.3333 & 0.5714 \\
\hline Big4 & 15582 & 0.0606 & 0.2386 & 0.0000 & 0.0000 & 1.0000 \\
\hline
\end{tabular}

Descriptive statistics for the main variables are listed in chart 2. As can be seen from chart 2, the average value of corporate financialization (Fin) of the company is 0.0771 , indicating that China's non-financial listed companies have financialization problems. The maximum value is 0.5841 , indicating that the investment of corporate financial assets in the sample accounts for more than 58\% 
of the total assets, indicating a high degree of financialization. The mean of strategic aggressiveness (STRA) was 11.8668, the median was 12.0000 , and the standard deviation was 4.0650 . This shows that overall, the strategic choice of China's listed companies is more aggressive, but there are obvious differences in the degree of strategic activism among different companies.

This paper makes a correlation analysis of the research variables and preliminarily clarifies the correlation between the degree of strategic aggressiveness and corporate financialization. As can be seen from chart 3 , the correlation coefficients among variables are all less than 0.5 , indicating that there is no serious multicollinearity problem. Financialization index (FIN) is positively correlated with strategic aggressiveness (STRA), and the correlation coefficient is 0.029 , which is significant at the level of $1 \%$, which can preliminarily support Hypothesis $1(\mathrm{H} 1)$ of this paper. That is, companies with high strategic aggressiveness have higher financialization degree relative to those with low strategic aggressiveness.

Table 3. Correlation analysis

\begin{tabular}{|c|c|c|c|c|c|c|c|c|c|c|c|c|c|}
\hline Variable & FIN & STRA & Size & Lev & ROA & Growth & Cash & First & Fund & Boardsize & Dual & Indep & Big4 \\
\hline FIN & 1 & & & & & & & & & & & & \\
\hline STRA & $\begin{array}{c}0.029 \\
* * *\end{array}$ & 1 & & & & & & & & & & & \\
\hline Size & $\begin{array}{c}- \\
0.041 \\
* * *\end{array}$ & $\begin{array}{c}-0.049 \\
* * *\end{array}$ & 1 & & & & & & & & & & \\
\hline Lev & $\begin{array}{c}- \\
0.127 \\
* * *\end{array}$ & $\begin{array}{c}-0.079 \\
* * *\end{array}$ & $\begin{array}{c}0.305 \\
* * *\end{array}$ & 1 & & & & & & & & & \\
\hline ROA & $\begin{array}{c}0.024 \\
* * * \\
\end{array}$ & $\begin{array}{c}0.081 \\
* * *\end{array}$ & $\begin{array}{c}0.102 \\
* * * \\
\end{array}$ & $\begin{array}{c}-0.331 \\
* * * \\
\end{array}$ & 1 & & & & & & & & \\
\hline Growth & $\begin{array}{c}0.065 \\
* * *\end{array}$ & $\begin{array}{c}0.212 \\
* * *\end{array}$ & $\begin{array}{c}0.065 \\
* * *\end{array}$ & $\begin{array}{c}0.018 \\
* *\end{array}$ & $\begin{array}{c}0.196 \\
* * *\end{array}$ & 1 & & & & & & & \\
\hline Cash & $\begin{array}{c}- \\
0.014 \\
*\end{array}$ & -0.003 & $\begin{array}{c}0.099 \\
* * *\end{array}$ & $\begin{array}{c}-0.135 \\
* * *\end{array}$ & $\begin{array}{c}0.238 \\
* * *\end{array}$ & $\begin{array}{c}0.016 \\
* *\end{array}$ & 1 & & & & & & \\
\hline First & $\begin{array}{c}-\overline{0} \\
0.031 \\
* * *\end{array}$ & $\begin{array}{c}-0.106 \\
* * *\end{array}$ & $\begin{array}{c}0.280 \\
* * *\end{array}$ & $\begin{array}{c}0.082 \\
* * *\end{array}$ & $\begin{array}{c}0.106 \\
* * *\end{array}$ & $\begin{array}{l}0.026 \\
* * *\end{array}$ & $\begin{array}{c}0.082 \\
* * *\end{array}$ & 1 & & & & & \\
\hline Fund & $\begin{array}{c}- \\
0.007 \\
\end{array}$ & $\begin{array}{c}-0.061 \\
* * * \\
\end{array}$ & $\begin{array}{c}0.678 \\
* * * \\
\end{array}$ & $\begin{array}{c}0.162 \\
* * * \\
\end{array}$ & $\begin{array}{c}0.045 \\
* * *\end{array}$ & 0.009 & $\begin{array}{c}0.121 \\
* * *\end{array}$ & $\begin{array}{c}0.230 \\
* * *\end{array}$ & 1 & & & & \\
\hline Boardsize & $\begin{array}{c}- \\
0.052 \\
* * *\end{array}$ & $\begin{array}{c}-0.071 \\
* * *\end{array}$ & $\begin{array}{l}0.238 \\
* * *\end{array}$ & $\begin{array}{l}0.139 \\
* * *\end{array}$ & $\begin{array}{c}0.047 \\
* * *\end{array}$ & -0.009 & $\begin{array}{c}0.062 \\
* * *\end{array}$ & $\begin{array}{c}0.075 \\
* * *\end{array}$ & $\begin{array}{c}0.143 \\
* * *\end{array}$ & 1 & & & \\
\hline Dual & $\begin{array}{c}0.024 \\
* * *\end{array}$ & $\begin{array}{c}0.083 \\
* * *\end{array}$ & $\begin{array}{c}-0.096 \\
* * *\end{array}$ & $\begin{array}{c}-0.083 \\
* * *\end{array}$ & -0.005 & $0.014 *$ & $\begin{array}{c}0.019 \\
* *\end{array}$ & $\begin{array}{c}-0.112 \\
* * *\end{array}$ & $\begin{array}{c}-0.060 \\
* * *\end{array}$ & $\begin{array}{l}-0.189 \\
* * *\end{array}$ & 1 & & \\
\hline Indep & 0.012 & $\begin{array}{c}0.041 \\
* * *\end{array}$ & $\begin{array}{c}0.042 \\
* * *\end{array}$ & -0.012 & $\begin{array}{c}-0.040 \\
* * *\end{array}$ & -0.005 & $\begin{array}{c}0.023 \\
* * *\end{array}$ & $\begin{array}{c}0.015 \\
*\end{array}$ & $\begin{array}{c}0.089 \\
* * *\end{array}$ & $\begin{array}{c}-0.463 \\
* * *\end{array}$ & $\begin{array}{c}0.102 \\
* * *\end{array}$ & 1 & \\
\hline Big4 & $\begin{array}{c}0.022 \\
* * *\end{array}$ & $\begin{array}{c}-0.048 \\
* * *\end{array}$ & $\begin{array}{c}0.358 \\
* * *\end{array}$ & $\begin{array}{c}0.076 \\
* * *\end{array}$ & $\begin{array}{c}0.061 \\
* * *\end{array}$ & -0.006 & $\begin{array}{c}0.066 \\
* * *\end{array}$ & $\begin{array}{c}0.162 \\
* * *\end{array}$ & $\begin{array}{c}0.446 \\
* * *\end{array}$ & $\begin{array}{c}0.088 \\
* * *\end{array}$ & $\begin{array}{c}0.049 \\
* * *\end{array}$ & $\begin{array}{c}0.036 \\
* * *\end{array}$ & 1 \\
\hline
\end{tabular}

\subsection{Multiple Regression Results Analysis}

From the multiple regression results of strategic aggressiveness and corporate financialization in chart 4, column (1) reports the regression results of financialization indicator (FIN) without adding any control variables. The regression coefficient of FIN is 0.0008 , which is significantly positive at the significance level of $1 \%$. In column (2), other control variables describing company characteristics are added. The results show that the coefficient of the core explaining variable strategic aggressiveness (STRA) is 0.0009 , which is still positively significant at the significance level of $1 \%$. The regression results of column (3) increase control variables for year and industry, and the regression coefficient of strategic aggressiveness (STRA) is still positive significantly. Therefore, the improvement of corporate strategy aggressiveness will increase the proportion of financial assets of the company and improve the degree of corporate financialization, which verifies the research hypothesis 1 (H1) in this paper. This indicates that companies with a high degree of strategic aggressiveness are more inclined to enter high-risk and high-yield fields such as finance, and increase 
investment in financial assets by increasing the proportion of financial assets, which promotes the improvement of financialization degree of enterprises.

Table 4. Multiple regression results

\begin{tabular}{|c|c|c|c|}
\hline \multirow{2}{*}{ Variable } & FIN & FIN & FIN \\
\hline & (1) & (2) & (3) \\
\hline \multirow{2}{*}{ STRA } & $0.0008 * * *$ & $0.0009 * * *$ & $0.0009 * * *$ \\
\hline & (3.54) & (3.93) & (4.31) \\
\hline \multirow{2}{*}{ Size } & & 0.0001 & $0.0026^{* *}$ \\
\hline & & $(0.11)$ & $(2.21)$ \\
\hline \multirow{2}{*}{ Lev } & & $-0.0661 * * *$ & $-0.0939 * * *$ \\
\hline & & $(-11.92)$ & $(-15.09)$ \\
\hline \multirow{2}{*}{ ROA } & & 0.0064 & -0.0164 \\
\hline & & $(0.37)$ & $(-0.96)$ \\
\hline \multirow{2}{*}{ Growth } & & $-0.0151 * * *$ & $-0.0153^{* * *}$ \\
\hline & & $(-7.92)$ & $(-8.13)$ \\
\hline \multirow{2}{*}{ Cash } & & $-0.0194 * * *$ & $-0.0386^{* * *}$ \\
\hline & & $(-2.71)$ & $(-5.47)$ \\
\hline \multirow{2}{*}{ First } & & $-0.0001 * *$ & -0.0001 \\
\hline & & $(-2.16)$ & $(-1.48)$ \\
\hline \multirow{2}{*}{ Fund } & & $0.0000 * * *$ & $0.0000 * * *$ \\
\hline & & $(4.51)$ & (3.34) \\
\hline \multirow{2}{*}{ Boardsize } & & $-0.0254 * * *$ & $-0.0367 * * *$ \\
\hline & & $(-4.88)$ & $(-7.24)$ \\
\hline \multirow{2}{*}{ Dual } & & $-0.0121 * * *$ & $-0.0090^{* * *}$ \\
\hline & & $(-5.90)$ & $(-4.52)$ \\
\hline \multirow{2}{*}{ Indep } & & -0.0232 & $-0.0329 *$ \\
\hline & & $(-1.31))$ & $(-1.95)$ \\
\hline \multirow{2}{*}{ Big4 } & & $-0.0098 * * *$ & $-0.0099 * * *$ \\
\hline & & $(-2.77)$ & $(-2.92)$ \\
\hline \multirow{2}{*}{ Constant } & $0.0679 * * *$ & $0.1691 * * *$ & $0.1516^{* * *}$ \\
\hline & (25.52) & $(6.72)$ & $(5.85)$ \\
\hline $\mathrm{N}$ & 15582 & 15582 & 15582 \\
\hline Adj_R2 & 0.0008 & 0.0255 & 0.1225 \\
\hline
\end{tabular}

\subsection{Further Examination and Analysis}

From the above analysis, it can be seen that the improvement of corporate strategy aggressiveness has promoted the level of corporate financialization, but it does not exclude whether other factors have different driving effects on financialization.

This paper further explores the difference in the impact of strategic aggressiveness on corporate financialization in the case of different corporate profitability. Yang Songling et al. (2019) believe that enterprises using idle funds for short-term financial investment can increase the liquidity of enterprises' assets, maintain and increase the value of capital, and help enterprises to better carry out technological innovation to achieve further development. More and more non-financial enterprises will choose to participate in transactions in the financial market (Stockhammer et al., 2010), believing that financial investment can bring rich profits, which enables enterprises to carry out innovative activities and promote their investment in technological innovation indirectly. The motivation of corporate financialization comes from the profit motive of enterprise. In this paper, the profitability of an enterprise is described by net profit. The larger this variable is, the stronger the profitability of the enterprise is. In this paper, the quant of net profit was used to make group adjustment. The results are shown in chart 5: Column (1) lists the regression results of the position where net profit is greater than $75 \%$, that is, the group with strong profitability; Column (2) lists the regression results of the position where net profit is less than $25 \%$, that is, the group with weak profitability. It shows that 
enterprises with weak profitability have stronger profit motive, which is more likely to lead to a higher level of financialization.

This paper further considers the impact of analyst attention on the relationship between corporate strategy aggressiveness and corporate financialization. On the one hand, securities analysts are important information intermediaries in the capital market. On the other hand, they are also an important external governance mechanism (Du et al., 2014). For example, Sun (2009), Sun et al. (2011) conducted related studies. In this paper, the specific group adjustment results of the quartiles of analyst attention are shown in column (3) and (4) of the chart below. Column (3) represents the value of the position with analyst attention greater than $75 \%$, that is, the group with high analyst attention; Column (4) represents the value of the position with less than $25 \%$ analyst attention, that is, the group with low analyst attention. Analyst attention is concerned about the influence of corporate financial behavior often through governance channels ( $\mathrm{Yu}, 2008)$ and information channels (Zhang Chun and Lu Wei, 2009) (Barth et al., 2001). The results of group adjustment also show that companies that are closely watched by analysts also have higher levels of financialization

Table 5. Group adjustment result

\begin{tabular}{|c|c|c|c|c|}
\hline & FIN & FIN & FIN & FIN \\
\hline Variable & $\begin{array}{c}\text { Strong } \\
\text { profitability } \\
\text { (1) }\end{array}$ & $\begin{array}{c}\text { Weak } \\
\text { profitability } \\
\text { (2) }\end{array}$ & $\begin{array}{c}\text { High analyst attention } \\
\text { (3) }\end{array}$ & $\begin{array}{c}\text { Low analyst attention } \\
\text { (4) }\end{array}$ \\
\hline \multirow{2}{*}{ STRA } & 0.0005 & $0.0019 * * *$ & $0.0010 * * *$ & 0.0012 \\
\hline & $(1.02)$ & $(4.29)$ & $(2.87)$ & $(1.64)$ \\
\hline \multirow{2}{*}{ Size } & $0.0194 * * *$ & -0.0012 & $-0.0034 * *$ & $0.0115^{* *}$ \\
\hline & $(5.68)$ & $(-0.51)$ & $(-2.06)$ & $(2.16)$ \\
\hline \multirow{2}{*}{ Lev } & $-0.1669 * * *$ & $-0.0602 * * *$ & $-0.0849 * * *$ & $-0.1300 * * *$ \\
\hline & $(-11.16)$ & $(-5.93)$ & $(-9.22)$ & $(-6.00)$ \\
\hline \multirow{2}{*}{ ROA } & 0.0394 & $-0.0535^{*}$ & -0.0280 & 0.0882 \\
\hline & $(0.74)$ & $(-1.88)$ & $(-1.21)$ & $(1.51)$ \\
\hline \multirow{2}{*}{ Growth } & $-0.0137 * * *$ & -0.0067 & $-0.0155 * * *$ & $-0.0164 * * *$ \\
\hline & $(-4.25)$ & $(-1.15)$ & $(-4.13)$ & $(-3.93)$ \\
\hline \multirow{2}{*}{ Cash } & $-0.0396 * * *$ & $-0.0332 * * *$ & $-0.0377 * * *$ & $-0.0440^{*}$ \\
\hline & $(-2.66)$ & $(-2.77)$ & $(-3.48)$ & $(-1.92)$ \\
\hline \multirow{2}{*}{ First } & $-0.0003 * *$ & 0.0000 & $-0.0003 * * *$ & 0.0002 \\
\hline & $(-2.28)$ & $(0.18)$ & $(-3.20)$ & $(1.10)$ \\
\hline \multirow{2}{*}{ Fund } & $-0.0000 * *$ & 0.0000 & $0.0000 * * *$ & 0.0001 \\
\hline & $(-2.22)$ & $(1.39)$ & $(4.37)$ & $(0.98)$ \\
\hline \multirow{2}{*}{ Boardsize } & $-0.0484 * * *$ & $-0.0544 * * *$ & $-0.0383 * * *$ & -0.0216 \\
\hline & $(-5.14)$ & $(-5.49)$ & $(-4.82)$ & $(-1.23)$ \\
\hline \multirow{2}{*}{ Dual } & -0.0045 & $-0.0140 * * *$ & $-0.0122 * * *$ & $-0.0106^{*}$ \\
\hline & $(-1.09)$ & $(-3.52)$ & $(-3.88)$ & $(-1.68)$ \\
\hline \multirow{2}{*}{ Indep } & -0.0096 & $-0.1266 * * *$ & $-0.0591 * *$ & 0.0649 \\
\hline & $(-0.30)$ & $(-3.78)$ & $(-2.19)$ & $(1.06)$ \\
\hline \multirow{2}{*}{ Big4 } & $-0.0178 * * *$ & 0.0048 & $-0.0100 * *$ & -0.0065 \\
\hline & $(-4.12)$ & $(0.53)$ & $(-2.08)$ & $(-0.40)$ \\
\hline \multirow{2}{*}{ Constant } & $-0.1729 * *$ & $0.2742 * * *$ & $0.3033 * * *$ & -0.0770 \\
\hline & $(-2.19)$ & $(5.41)$ & $(8.01)$ & $(-0.68)$ \\
\hline $\mathbf{N}$ & 3890 & 3896 & 6720 & 1770 \\
\hline$\overline{A d j \_R^{2}}$ & 0.1755 & 0.1069 & 0.1136 & 0.1570 \\
\hline
\end{tabular}

\section{Robustness Test}

In this paper, the method of substitution variables, cluster and Heckman is used to re-conduct multiple regressions. Further tests were conducted to improve the robustness of the results. 


\subsection{Substitution Variables}

Based on the practices of Milberg (2008) and Zhang Chengsi et al. (2016), this paper uses income instead of assets as the measurement index of corporate financialization (FIN1). The results show that no matter which financialization measurement method is adopted, the regression coefficient of strategic aggressiveness degree (STRA) is significantly positive, that is, the higher the strategic aggressiveness degree of the company, the higher the financialization degree, which is consistent with the above conclusion.

\subsection{Cluster}

In order to make the regression results more robust, this paper conducts a clustering process on the standard error of regression coefficients at the company level. After using the same control variables and controlling for year and industry effect, the company strategic aggressiveness (STRA) is still significantly positive at the significance level of $10 \%$. The degree of corporate strategy aggressiveness is positively correlated with the degree of corporate financialization, indicating that the more aggressive the corporate strategy is, the higher the level of corporate financialization will be, which also supports Hypothesis 1 (H1) of this paper.

\subsection{Heckman}

In this paper, according to the practices of Bentley et al. (2013) and Meng Qingbin et al. (2019), the samples with STRA $>=18$ are defined as offensive type, the samples with STRA $<=6$ are defined as defensive type, and the samples in between are defined as analytical type. After deletes the samples of analytical type, a variable of $0-1$ is defined. When the strategic aggressiveness is offensive type, it is 1 , and when it is defensive type, it is 0 . This paper uses Heckman two-stage regression to control the endogenous problem. The regression uses the same control variables as the main regression analysis, and it also controls industry and year.The regression coefficient of strategic aggressiveness (STRA) is still significantly positive, suggesting that after controlling the endogenous, company with more strategic aggressiveness still has a higher level of financialization. Therefore, the conclusion remains robust in the paper.

\section{Conclusion}

This paper takes Chinese A-share listed companies of Shanghai and Shenzhen stock market from 2007 to 2018 as research samples to empirically analyze the impact of strategic aggressiveness on corporate financialization. The results show that: (1) The more aggressive the corporate strategy is, the more likely it is to promote real firms financialization. Moreover, the research conclusions remain stable and unchanged after changing the measurement method of the research variables, companylevel cluster analysis and Heckman two-stage regression. (2) The positive effect of corporate strategy on corporate financialization is more significant in the enterprises with weak profitability and high analyst attention.

The research results of this paper have important reference value for us to understand the influence of corporate strategy on corporate financialization, and contribute to the continuous enrichment of the research on the influencing factors of corporate financialization. In the context of China's economic transformation, the financialization trend of China's real enterprises is obvious. The situation of "moving from real economy to virtual economy" and the requirements of preventing and controlling financial risks are still severe. The study of this paper has certain practical significance and reference value in the strategic choice of non-financial enterprises, especially non-financial listed companies. If the strategic choice of entity enterprises is too aggressive, it is likely to ignore financial risks and over-allocate financial assets, resulting in a serious financialization tendency. Therefore, making a reasonable strategic choice and controlling the level of strategic radicalization can reduce the risk of excessive financialization to a certain extent. At the same time, from the perspective of financialization motivation and external control, this paper also discusses the regulating effect of 
profitability and analyst attention on the relationship between corporate strategy and financialization, which provides a new idea for regulators to pay more attention to enterprises with weak profitability and high analyst attention to prevent financialization risks.

This paper still has the following limitations: on the one hand, this paper only confirms the positive impact of corporate strategy on corporate financialization, and does not confirm the conclusions of this paper from the perspective of opposing assumptions; On the other hand, this paper does not further explore the consequences of the impact of corporate strategy on corporate financialization.

Table 6. Substitution variables results

\begin{tabular}{|c|c|c|c|}
\hline \multirow{2}{*}{ Variable } & FIN1 & FIN1 & FIN1 \\
\hline & (1) & (2) & (3) \\
\hline \multirow{2}{*}{ STRA } & $-4.6590 * * *$ & 1.6909 & $2.0775^{*}$ \\
\hline & $(-2.92)$ & $(1.41)$ & $(1.72)$ \\
\hline \multirow{2}{*}{ Size } & & $-57.6035^{* * *}$ & $-63.3848^{* * *}$ \\
\hline & & $(-3.44)$ & $(-3.49)$ \\
\hline \multirow{2}{*}{ Lev } & & -28.4737 & 5.5838 \\
\hline & & $(-1.11)$ & $(0.21)$ \\
\hline \multirow{2}{*}{ ROA } & & $695.6795^{* * *}$ & $718.0152^{* * *}$ \\
\hline & & $(5.96)$ & $(6.04)$ \\
\hline \multirow{2}{*}{ Growth } & & $-30.7642 * * *$ & $-32.5629 * * *$ \\
\hline & & $(-4.62)$ & $(-4.87)$ \\
\hline \multirow{2}{*}{ Cash } & & $-3.0 \mathrm{e}+02 * * *$ & $-2.7 \mathrm{e}+02 * * *$ \\
\hline & & $(-6.65)$ & $(-7.65)$ \\
\hline \multirow{2}{*}{ First } & & $1.7393 * * *$ & $2.0107 * * *$ \\
\hline & & $(2.79)$ & $(3.06)$ \\
\hline \multirow{2}{*}{ Fund } & & $2.5443 * * *$ & $2.5749 * * *$ \\
\hline & & (7.73) & $(7.67)$ \\
\hline \multirow{2}{*}{ Boardsize } & & -42.2451 & -23.5911 \\
\hline & & $(-0.86)$ & $(-0.52)$ \\
\hline \multirow{2}{*}{ Dual } & & $-23.6745^{* * *}$ & $-29.0340 * * *$ \\
\hline & & $(-3.09)$ & $(-3.27)$ \\
\hline \multirow{2}{*}{ Indep } & & $-2.9 \mathrm{e}+02 *$ & $-2.8 \mathrm{e}+02 *$ \\
\hline & & $(-1.83)$ & $(-1.73)$ \\
\hline \multirow{2}{*}{ Big4 } & & $139.3846^{* * *}$ & $143.1895 * * *$ \\
\hline & & $(3.28)$ & $(3.37)$ \\
\hline \multirow{2}{*}{ Constant } & $180.1888^{* * *}$ & $1.4 \mathrm{e}+03 * * *$ & $1.4 \mathrm{e}+03 * * *$ \\
\hline & $(7.74)$ & $(3.11)$ & $(3.13)$ \\
\hline $\mathrm{N}$ & 15582 & 15582 & 15582 \\
\hline Adj_R2 & 0.0004 & 0.1895 & 0.1904 \\
\hline
\end{tabular}

Table 7. Cluster results

\begin{tabular}{|c|c|c|c|}
\hline \multirow{2}{*}{ Variable } & FIN & FIN & FIN \\
\cline { 2 - 4 } & $(1)$ & $(2)$ & $(3)$ \\
\hline \multirow{2}{*}{ STRA } & 0.000 & 0.0009 & $0.0009^{*}$ \\
\cline { 2 - 4 } & $(1.43)$ & $(1.63)$ & $(1.83)$ \\
\hline \multirow{2}{*}{ Size } & & 0.0001 & 0.0026 \\
\cline { 2 - 4 } & & $(0.05)$ & $(0.94)$ \\
\hline \multirow{2}{*}{ Lev } & & $-0.0661^{* * *}$ & $-0.0939^{* * *}$ \\
\hline \multirow{2}{*}{ ROA } & & $(-5.17)$ & $-(-6.37)$ \\
\cline { 2 - 4 } & & 0.0064 & $(-0.66)$ \\
\hline \multirow{2}{*}{ Growth } & & $(0.25)$ & $-0.0153^{* * *}$ \\
\cline { 2 - 4 } & & $-0.0151^{* * *}$ & $(-7.90)$ \\
\hline \multirow{2}{*}{ Cash } & & $(-7.57)$ & $-0.0386^{* * *}$ \\
\cline { 2 - 4 } & & -0.0194 & $(-3.15)$ \\
\hline
\end{tabular}


Volume 15 (2021)

\begin{tabular}{|c|c|c|c|}
\hline \multirow{2}{*}{ First } & & -0.0001 & -0.001 \\
\cline { 2 - 4 } & & $(-0.81)$ & $(-0.57)$ \\
\hline \multirow{2}{*}{ Fund } & & $0.0000^{*}$ & 0.0000 \\
\cline { 2 - 4 } & & $(1.94)$ & $(1.42)$ \\
\hline \multirow{2}{*}{ Boardsize } & & $-0.0254^{* *}$ & $-0.0367^{* * *}$ \\
\cline { 2 - 4 } & & $(-1.98)$ & $(-3.02)$ \\
\hline \multirow{2}{*}{ Dual } & & $-0.0121^{* * *}$ & $-0.0090^{* *}$ \\
\cline { 2 - 4 } & & $(-3.00)$ & $-2.37)$ \\
\hline \multirow{2}{*}{ Indep } & & -0.0232 & $(-0.929$ \\
\cline { 2 - 4 } & & $(-0.60)$ & -0.0099 \\
\hline \multirow{2}{*}{ Big4 } & & -0.0098 & $(-1.13)$ \\
\hline \multirow{2}{*}{ Constant } & & $(-1.05)$ & $0.1516^{* *}$ \\
\hline \multirow{2}{*}{$\mathrm{N}$} & $0.0679^{* * *}$ & $0.1691^{* * *}$ & $(2.49)$ \\
\hline Adj_R2 & $(10.33)$ & $(2.77)$ & 15582 \\
\hline & 15582 & 15582 & 0.1225 \\
\hline
\end{tabular}

Table 8. Heckman results

\begin{tabular}{|c|c|c|}
\hline \multirow{2}{*}{ Variable } & FIN & FIN1 \\
\hline & (1) & (2) \\
\hline \multicolumn{3}{|l|}{ Main } \\
\hline \multirow{2}{*}{ STRA } & $0.0052 *$ & $26.7167 * * *$ \\
\hline & $(1.86)$ & $(2.73)$ \\
\hline \multirow{2}{*}{ Size } & -0.0046 & -27.2809 \\
\hline & $(-0.98)$ & $(-1.63)$ \\
\hline \multirow{2}{*}{ Lev } & $-0.1271 * * *$ & $-1.1 \mathrm{e}+02$ \\
\hline & $(-6.58)$ & $(-1.59)$ \\
\hline \multirow{2}{*}{ ROA } & -0.0823 & $808.1774 * * *$ \\
\hline & $(-1.51)$ & (4.14) \\
\hline \multirow{2}{*}{ Growth } & -0.0037 & 18.3488 \\
\hline & $(-0.47)$ & $(0.64)$ \\
\hline \multirow{2}{*}{ Cash } & $-0.0530 * * *$ & -90.2915 \\
\hline & $(-3.12)$ & $(-1.48)$ \\
\hline \multirow{2}{*}{ First } & $-0.0008 * * *$ & -1.0215 \\
\hline & $(-2.88)$ & $(-1.01)$ \\
\hline \multirow{2}{*}{ Fund } & $0.0002 * * *$ & $2.7621 * * *$ \\
\hline & $(4.12)$ & (15.38) \\
\hline \multirow{2}{*}{ Boardsize } & 0.0138 & 93.4267 \\
\hline & $(0.61)$ & (1.17) \\
\hline \multirow{2}{*}{ Dual } & -0.0052 & -9.5771 \\
\hline & $(-0.70)$ & $(-0.36)$ \\
\hline \multirow{2}{*}{ Indep } & $0.2663 * * *$ & $656.8569 * *$ \\
\hline & (3.67) & (2.54) \\
\hline \multirow{2}{*}{ Big4 } & 0.0077 & -43.4342 \\
\hline & $(0.41)$ & $(-0.66)$ \\
\hline \multirow{2}{*}{ Lamnda } & 0.0222 & $172.8697^{* *}$ \\
\hline & 1.07 & $(2.32)$ \\
\hline \multirow{2}{*}{ Constant } & -0.0042 & $-5.0 \mathrm{e}+02$ \\
\hline & $(-0.03)$ & $(-1.17)$ \\
\hline $\mathrm{N}$ & 2967 & 2967 \\
\hline
\end{tabular}




\section{References}

[1] Ang J, Smedema A. 2011. Financial flexibility: Do firms prepare for recession?. Journal of Corporate Finance, 17 (3): 774-787.

[2] Barth, M., R. Kasnik, and M. McNichols. 2001. "Analyst Coverage and Intangible Assets", Journal of Accounting Research, 39: 1-34.

[3] Bentley, K. A., T. C. Omer and N. Y. Sharp, 2013, "Business Strategy, Financial Reporting Irregularities and Audit Effort", Contemporary Accounting Research, Vol.30, No2, pp.780 817.

[4] Bessembinder, H. Forward Contracts and Firm Value: Investment Incentive and Contracting Effects[J]. Journal of Financial \& Quantitative Analysis, 1991, 26(4): 519-532.

[5] Cai Mingrong, shi-chi ren. Enterprise financialization: a research review [J]. Science of finance and economics, 2014, (7): 41-51.

[6] Collins, F., O. Holzmann and R. Mendoza, 1997, "Strategy, Budgeting and Crisis in Latin America", Accounting, Organi-zations and Society, Vol. 22, pp. 669 689.

[7] Cui A S, Calantone R J, Griffith D A. Strategic change and termination of interfirm partnerships. Strategic Management Journal, 2011, 32(4): 402- 423.

[8] Demir, F., 2009. Financial Liberation, Private Investment and Portfolio Choice: Financialization of Real Sectors in Emerging Markets. Journal of Development Economics, 88(2): 314-324.

[9] Deng Chao, Zhang Mei, Tang Ying. Analysis of Factors Influencing Financialization of Chinese Nonfinancial Enterprises [J]. Financial Theory \& Practice, 2017, (2): 2-8.

[10] Denis D J, Sibilkov V. 2010. Financial constraints, investment, and the value of cash holdings. Review of Financial Studies, 23(1): 247-269.

[11] Dichev I D, Graham J R, Harvey C R, et al. 2013. Earnings quality: Evidence from the field. Journal of Accounting \& Economics, 56(2-3): 1-33.

[12] Dimaggio P J, Powell W W. 1983. The iron cage revisited: Institutional isomorphism and collective rationality in organizational fields. American Sociological Review, 48(2): 147-160.

[13] Du Yong, Xie Jin jian-ying Chen, CEO of financial background and entity enterprise financialization [J]. China industrial economy, 2019 (5): 136-154.

[14] Du, X. 2014. "Does Religion Mitigate Tunneling? Evidence from Chinese Buddhism", Journal of Business Ethics, 125 (2): 299-327.

[15] Fang Hongxing, Chu Youwei. Corporate strategy and commercial credit financing [J]. Nankai Management Review,2019,22(05):142-154.

[16] Francis, J., and A. Smith, 1995, "Agency Costs and Innovation Some Empirical Evidence", Journal of Accounting and Economics, 19(2-3): 383-409.

[17] Gao Zhlin, Chen Yan. Corporate Strategy Develation, CFO Financial Execution and Corporate Cash Holding Level [J]. Economic Journal,20,37(02):115-124.

[18] He Xiqiong, Yin Changping. An Empirical Study on the Influence of Corporate Strategy Difference on Earnings Forecast of Analysts [J]. Nankai Management Review, 2018,21 (2): 149-159.

[19] Higgins, D., T. C. Omer, and J. D. Phillips. The Influence of a Firm's Business Strategy on Its Tax Aggressiveness [J]. Contemporary Accounting Research, 2015, 32(2): 674-702.

[20] Hu Yiming, Wang Xueting, Zhang Jin. Motivation of financial asset allocation: "reservoir" or "substitution"? Economic Research Journal, 2017, (1): 181-194. (In Chinese).

[21] Ittner, C. D., D. F. Larcker and M. V. Rajan, 1997, "The Choice of Performance Measures in Annual Bonus Con-tracts", Accounting Review, Vol.72, No. 2, pp. 231-255.

[22] Keynes, J. M., 1936, The General Theory of Interest, Employment and Money, London: Macmillan.

[23] Krippner, Greta, 2005. The Financialization of the American Economy. Socio-Economic Review, 3(2): 173-208.

[24] Liu Hang. Does the type of strategy of an enterprise affect the characteristics of earnings? Nankai Management Review, 2016, 19(4): 111-121.

[25] Meng Qingbin, Li Xinyu, Zhang Xiuping. Short selling mechanism, capital market pressure and firm strategic choice [J]. China Industrial Economy,2019(08):155-173. 
[26] Milberg, W.,2008, "Shifting Sources and Uses of Profits: Sustaining US Financialization with Global Value Chains", Economy and Society,37(3),420-451.

[27] Miles, R. E., and C. C. Snow. Organizational Strategy, Structure and Process [M]. Stanford, CA: Stanford University Press, 2003.

[28] Oehmichen J, Schrapp S, Wolff M. Who needs experts most? Board industry expertise and strategic change--a contingency perspective. Strategic Management Journal, 2017, 38(3): 645-656.

[29] Opler, T., L. Pinkowitz, R. Stulz, and R. Williamson, 1999, "The Determinants and Implications of Corporate Cash Holdings", Journal of Financial Economics, 52, 3-46.

[30] Orhangazi, O., 2008. Financialization and Capital Accumulation in the Non -financial Corporate Sector: A Theoretical and Empirical Investigation on the US Economy: 1973-2003. Cambridge Journal of Economics, 32(6): 863-886.

[31] Peng Yuchao, Han Xun, Li Jianjun. Economic Policy Uncertainty and Firm Financialization [J]. China Industrial Economics, 2018a, (1): 137-155.

[32] Stockhammer, E., and L. Grafl. Financial Uncertainty and Business Investment[J].Review of Political Economy,2010,22(4):551-568.

[33] Sun Jian, Wang Baiqiang, Cao Feng, Liu Xiangqiang. Does Corporate Strategy Influence Earnings Management? [J]. Management World,2016(03):160-169.

[34] Sun, J., and Guoping Liu. 2011. "Industry Specialist Auditors, Outsider Directors, and Financial Analysts", Journal of Account and Public Policy, 30(3): 367-382.

[35] Sun, J. 2009. “Governance Role of Analyst Coverage and Investor Protection”, Financial Analysts Journal, 65 (6): 1-13.

[36] Wang Hongjian, Cao Yuqiang, Yang Qing, et al. Real Firm Financialization Promotes or Restraints Firm Innovation: A Study Based on the Experience of Chinese Manufacturing Listed Companies [J]. Nankai Management Review, 2017,20 (1): 155-166.

[37] Wang Hongjian, Li Mangmang, Tang taijie, 2016. The driving factors of cross-industry arbitrage of real firms and its impact on innovation [J]. China Industrial Economics, (11): 73-89.

[38] Wu jun, Chen Liping. Non-financial companies financialization degree and the relationship between changes in leverage - from a-share listed companies and unlisted companies bond issuance of evidence [J]. Financial Forum,2018,23(01):3-15+51.

[39] Yang Jinfeng, Sun Weizhang, Yang Yang. CEO Power, Corporate Strategy and Audit Fees [J]. Journal of Tianjin University of Finance and Economics, 2019 (1): 99-113.

[40] Yang Songling, Niu Dengyun, Liu Tingli, Wang Zhihua. Journal of Management Science, 2019, (2):3-18. (In Chinese).

[41] Yu Minggui, Li Wengui, Pan Hongbo. Management Overconfidence and Corporate Risk Taking [J]. Financial Research, 2013(1): 149-163.

[42] Yu, F. 2008. “Analyst Coverage and Earnings Management”, Journal of Financial Economics, 88(4): 245 271.

[43] Yuan Rongli, Xia Shengjian, Wang Huacheng. Strategic radicalism and firm innovation [J]. Economic Theory and Management,2020(03):86-98. (In Chinese).

[44] Zhang Chengsi, Zhang Budan. The Mystery of the Decline of China's Industrial Investment Rate: From the Perspective of Economic Financialization [J]. Economic Research Journal, 2016, (12): 32-46.

[45] Zhang Chun and Lv Wei, 2009, "Information Environment, Financing Constraints and Cash Dividends", Journal of Finance, Vol.7, No.7, pp. 81-94. 